\title{
Corpus luteum dynamics after ovulation induction with or without previous exposure to progesterone in prepubertal Nellore heifers
}

\author{
Dayane Priscila Vrisman ${ }^{\text {a, }}$, Natália Marins Bastos ${ }^{a}$, Guilherme Fazan Rossi ${ }^{a}$, \\ Naiara Nantes Rodrigues a, Luisa Pucci Bueno Borges ${ }^{\text {b }}$, Augusto Ryonosuke Taira a, \\ Cláudia Cristina Paro de Paz ${ }^{c}$, Guilherme de Paula Nogueira ${ }^{\mathrm{d}}$, Pedro Paulo Maia Teixeira ${ }^{\text {b }}$, \\ Fábio Morato Monteiro ${ }^{\mathrm{c}}$, Maria Emília Franco Oliveira ${ }^{\mathrm{a}, *}$ \\ a Departamento de Medicina Veterinária Preventiva e Reprodução Animal, Universidade Estadual Paulista "Júlio de Mesquita Filho" (FCAV/UNESP), \\ Jaboticabal, São Paulo, 14884-900, Brazil \\ b Instituto de Medicina Veterinária, Universidade Federal do Pará, Belém, Pará, 66075-110, Brazil \\ ${ }^{\mathrm{c}}$ Instituto de Zootecnia, Centro APTA Bovinos de Corte, Sertãozinho, São Paulo, 14160-970, Brazil \\ ${ }^{\mathrm{d}}$ Laboratório de Endocrinologia Animal, Faculdade de Medicina Veterinária de Araçatuba (FMVA/UNESP), Araçatuba, São Paulo, 16050-680, Brazil
}

\section{A R T I C L E I N F O}

\section{Article history:}

Received 27 July 2017

Received in revised form

2 October 2017

Accepted 9 October 2017

Available online 13 October 2017

\section{Keywords:}

Short estrous cycle

Progesterone device

GnRH

Hormonal induction

Puberty

Premature luteolysis

\begin{abstract}
A B S T R A C T
The objectives of this study were 1 ) to monitor corpus luteum (CL) dynamics after two different protocols of ovulation induction in prepubertal Nellore heifers, and 2) to determine differences in luteal function. Fifty-seven heifers (weight $289.61 \pm 32.28 \mathrm{~kg}$, BCS $5.66 \pm 0.65$, age $17.47 \pm 0.81$ months) were divided into two groups: GP4 $+\mathrm{GnRH}$ received a progesterone (P4) device of 3rd use for 10 days, followed by the administration of $0.02 \mathrm{mg}$ buserelin acetate $(\mathrm{GnRH}) 48 \mathrm{~h}$ after removal of the device, and GGnRH received only GnRH. The CLs formed were monitored by ultrasonography every 2 days until their functional regression (decrease in the color Doppler signal and serum P4 concentration $<1 \mathrm{ng} / \mathrm{mL}$ ), determining their diameter and area, numerical pixel value (NPV), pixel heterogeneity, and vascularization percentage. The peak systolic velocity, end diastolic velocity, resistivity index and pulsatility index (PI) of the ovarian artery and serum P4 concentration were also measured. A lifespan of the CL of more than 16 days was classified as normal-function and of less than 16 days as premature regression. The variables were compared between treatments, CL categories (normal-functional, prematurely regressed or non-functional), days of evaluation, and their interactions using the MIXED procedure of the SAS program $(p \leq 0.05)$. Three animals of each group $(6 / 57=11 \%$ ) did not respond to treatment, corresponding to an ovulation rate of $89 \%$. There was a higher percentage of normal-function CLs in GP4+GnRH (81\%) and a higher percentage of non-functional CLs in GGnRH (52\%; P4 concentration $<1 \mathrm{ng} / \mathrm{mL}$ in all assessments). Normal-function CLs exhibited a greater area, vascularization percentage and P4 concentration than prematurely regressed and non-functional CLs. Lower diameter, area, NPV and P4 concentration were observed for non-functional CLs, but there was no difference in vascularization percentage compared to prematurely regressed CLs. Progesterone concentration was efficient in diagnosing CL function and was positively correlated with $\mathrm{CL}$ area $(\mathrm{r}=0.62$; $\mathrm{p}<0.001)$ and vascularization percentage $(\mathrm{r}=0.38 ; \mathrm{p}<0.001)$. Diameter and PI were important for the early diagnosis of non-functional and prematurely regressed CLs, respectively. In conclusion, luteal function differed for the first $\mathrm{CL}$ that develops after ovulation induction in prepubertal heifers. Ultrasonographic parameters (diameter, area, NPV, vascularization percentage, and PI) can be used to predict CL function.
\end{abstract}

๑) 2017 Elsevier Inc. All rights reserved.

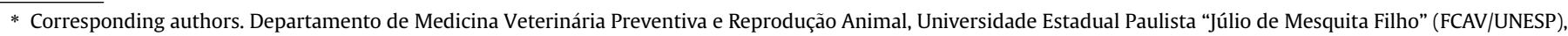
Via de Acesso Prof'. Paulo Donato Castellane, s/n, 14884-900, Jaboticabal, São Paulo, Brazil.
}

E-mail addresses: dayavrisman@hotmail.com (D.P. Vrisman), m_emiliafraoli@yahoo.com.br (M.E.F. Oliveira). 


\section{Introduction}

In heifers, puberty occurs when ovulation is followed by signs of estrus, with a subsequent normal length of the luteal phase for the species [1]. However, the first ovulation of heifers is often accompanied by premature regression of the corpus luteum (CL) [2]. Premature regression is defined as regression of the CL before day 16 of the estrous cycle [3] and occurs in heifers because the animals are not fully sexually mature [4]. Estrous manifestation and fertility increase over the first cycles so that the female acquires the capacity to conceive and carry the pregnancy to term [5].

Studies using ultrasonographic assessment of the $\mathrm{CL}$ provide important data about the reproductive status of female cattle, which permit to monitor the formation dynamics, development and regression of this structure [6,7]. The ultrasound image of the $\mathrm{CL}$ is uniform, circumscribed and less echogenic than the ovarian stroma [6]. Computer analysis allows to obtain more detailed information of the ultrasound images based on the frame-by-frame (pixel) identification of the intensity of the returning sound waves, reflected by the grayscale generated in the image, and can be used for the evaluation of echogenicity and echotexture of the CL [8]. Siqueira et al. [7] suggested echotexture as a potential measure to predict CL function and steroidogenic capacity, an area to be explored in future studies.

Color Doppler ultrasonography is a real-time imaging method of the vascular architecture of any structure that permits to estimate blood perfusion to the tissue and to evaluate the presence, direction and intensity of vascularization $[9,10]$. The pattern of CL vascularization varies across the estrous cycle, with an increase in blood flow at the beginning of formation of this structure and a decrease during its regression $[9,11]$.

Spectral Doppler assessment provides accurate values of vascularization-related indices, which allow comparisons of blood flow during systole and diastole and evaluation of the presence of stenosis or thrombosis. During the estrous cycle, changes occur in the spectral tracing of intraovarian artery flow, with the observation of an increase in the resistivity index (RI) during luteolysis [12]. A higher RI is associated with lower blood flow velocities and metabolically less active structures, while a lower index is related to higher velocities and metabolically active structures [13].

The study of luteal vascularization is important because the $\mathrm{CL}$ is the most vascularized tissue in the body of female cattle. In this respect, $65 \%-95 \%$ of the blood that reaches the ovary can be destined for irrigation of the $\mathrm{CL}$, which has the highest blood flow rates per tissue unit [14]. Luteal function establishes the duration and regularity of estrous cycles and is determined by the production of progesterone (P4). Some studies reported a correlation between CL size and P4 production, while others found no such effect [15-17]. According to some authors, CL function can be determined based on echotexture [18] and blood flow during the estrous cycle [16].

In view of the above considerations, the objectives of the present study were 1 ) to study the dynamics of CLs that develop in the first estrous cycle after ovulation induction in prepubertal Nellore heifers; 2) to evaluate differences between fully functional and prematurely regressed luteal structures; 3 ) to identify ultrasonographic characteristics for the early diagnosis of premature regression, and 4) to verify the correlation of P4 concentration with CL area and vascularization percentage and the relationship between variables that best contribute to the study. The hypothesis of this study was that ultrasonographic parameters can be used to distinguish between normal-function and prematurely regressed luteal structures in cattle.

\section{Material and methods}

\subsection{Study area}

The experiment was conducted at Instituto de Zootecnia (Centro Avançado de Pesquisa Tecnológica do Agronegócio de Bovinos de Corte; latitude: $21^{\circ} 10^{\prime}$ south, longitude: $48^{\circ} 5^{\prime}$ west), Sertãozinho, São Paulo, Brazil, between March and May 2016. The study was approved by the Ethics Committee of Universidade Estadual Paulista "Júlio de Mesquita Filho" (UNESP), Jaboticabal (Protocol Number 12146/15).

Nellore heifers were kept in rotational paddock systems on Brachiaria pasture with mineral salt and water ad libitum. Energy (corn silage ad libitum) and protein supplements (soybean meal, $0.5 \mathrm{~kg} /$ head/day) were provided during the evaluation period.

\subsection{Animals and treatment}

Sixty-two Nellore heifers with a mean body weight of $289.61 \pm 32.28 \mathrm{~kg}$, body condition score (BCS) of $5.66 \pm 0.65$ (score of 1-9) [19] and age of $17.47 \pm 0.81$ months were evaluated regarding reproductive cyclicity. Fifty-seven animals were classified as prepubertal based on the absence of a CL in two ultrasonographic assessments (Mindray Z $5^{\circledR}$, Shenzhen, China) performed at an interval of 7 days.

Twenty-nine heifers were submitted to ovulation induction on a random day of follicular development using an intravaginal P4 device and inducer of ovulation (GP4+GnRH) as shown in Fig. 1-A. For this purpose, on day -12 (D-12), an intravaginal P4 device of 3rd use (CIDR ${ }^{\circledR}$, Zoetis, São Paulo, Brazil) was inserted for a period of 10 days and removed on D-2. On D0 (48 h after removal of the P4 device), $0.02 \mathrm{mg}$ buserelin acetate (Sincroforte ${ }^{\circledR}$, Ouro Fino, São Paulo, Brazil), a synthetic gonadotrophin-releasing hormone (GnRH) analog, was applied intramuscularly.

In the remaining 28 animals, ovulation was induced only with GnRH (GGnRH) as shown in Fig. 1-B. In this group, three assessments were performed prior to treatment to verify female cyclicity. The inducer of ovulation was the same as in the previous treatment and was administered at the same concentration and by the same route.

The diameter of the largest follicle was measured on the day of ovulation induction to evaluate the ovulatory response to the two treatments. The experimental protocols were designed to permit the formation of normal length and prematurely regressed CLs in both treatments and their subsequent analysis and comparison based on ultrasonographic characteristics.

\subsection{Evaluation of the corpus luteum after ovulation induction}

Ultrasonographic assessment was started $48 \mathrm{~h}$ after administration of GnRH in both groups for the confirmation of ovulation (absence of the dominant follicle) and for CL evaluation in heifers in which this structure was detected. Animals that did not respond to treatment (absence of a CL up to $96 \mathrm{~h}$ after $\mathrm{GnRH}$ administration) were excluded from the analyses.

The CLs formed were evaluated until the decrease in the vascular signal (monitored by color Doppler ultrasonography). Color Doppler imaging was used to determine the end of the assessments since the main objective was to evaluate CL function. After this identification, two additional evaluations were performed at intervals of 2 days (Fig. 1). For ultrasonographic assessment, B-mode, color and spectral Doppler images were obtained 
(A) $\mathrm{GP} 4+\mathrm{GnRH}(\mathrm{n}=29)$

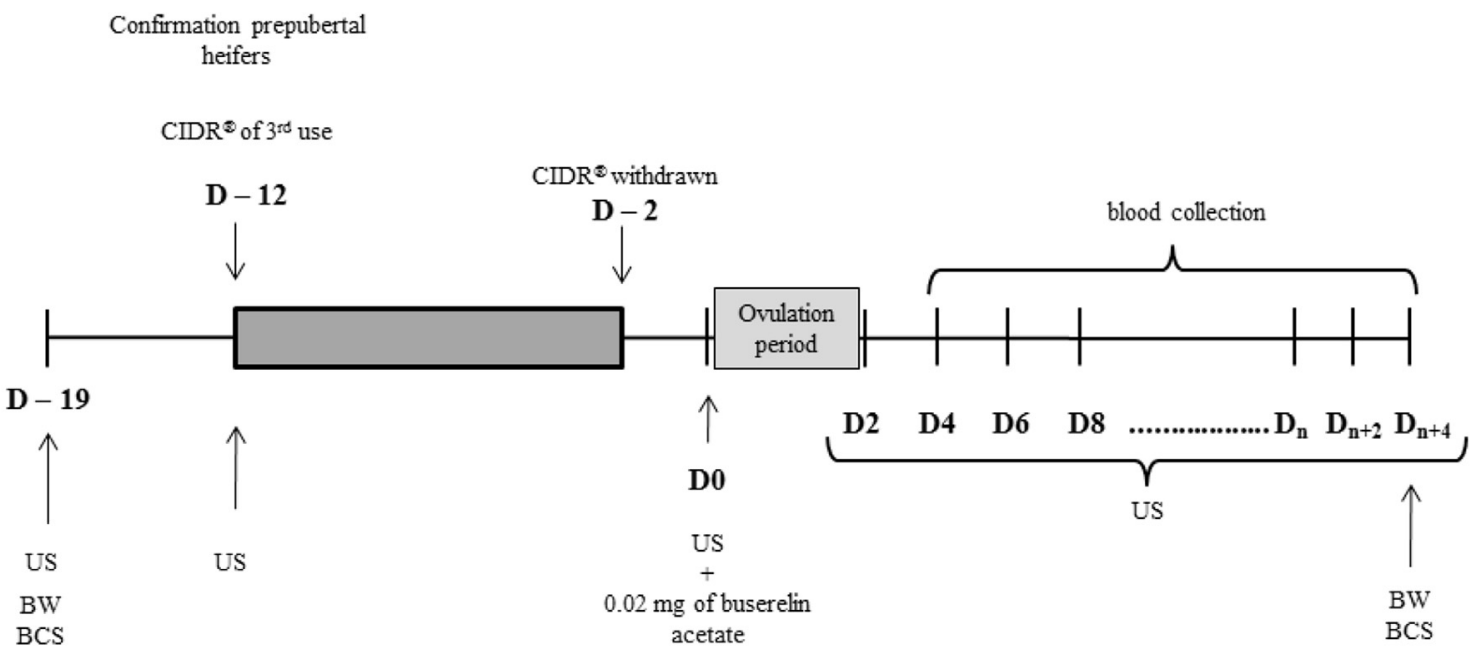

(B) $G G n R h(n=28)$

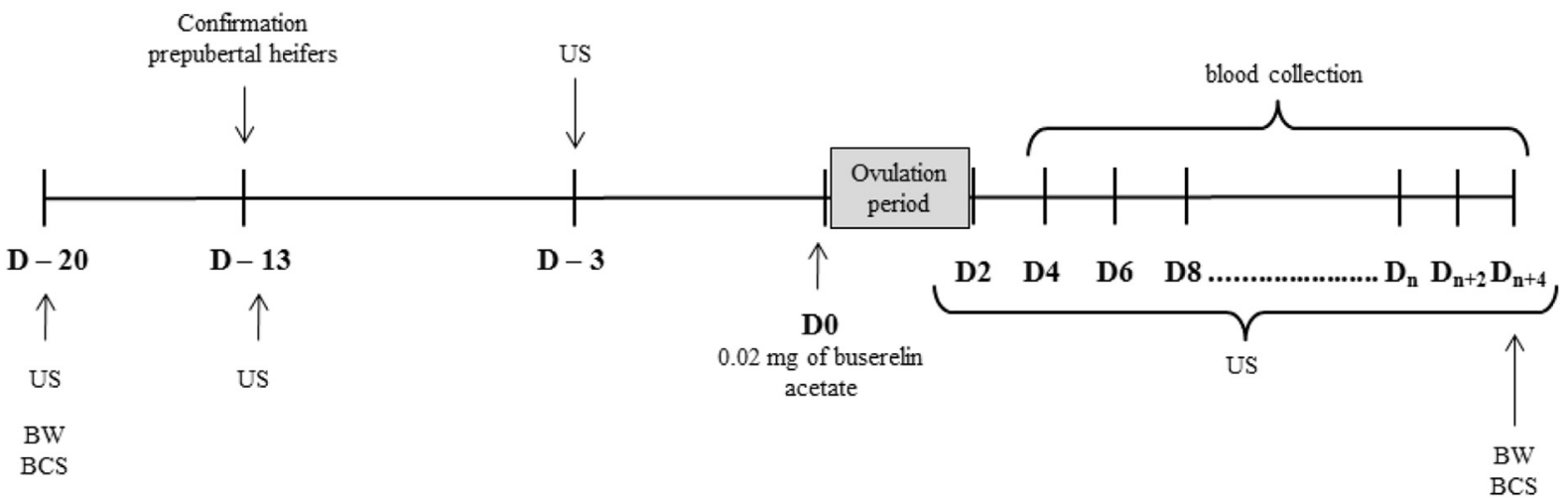

Fig. 1. Schematic representation of the experimental design. (A): treatment with progesterone device and ovulation inducer; (B): treatment only with ovulation inducer.

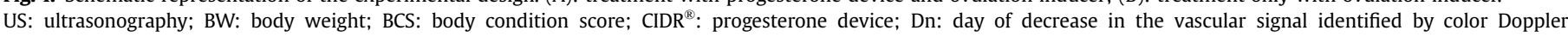
ultrasonography.

using a multifrequency (7.5 MHz) linear transrectal transducer.

The CLs were first detected by conventional ultrasound and Bmode scans and color Doppler imaging were used for subsequent analysis. Next, spectral Doppler ultrasonography of the ovarian artery was performed and, finally, blood was collected for the measurement of serum P4 concentration to confirm luteal function.

The length of the luteal phase of each animal based on $\mathrm{CL}$ function was defined as the period from $24 \mathrm{~h}$ after $\mathrm{GnRH}$ administration (range: $26-30 \mathrm{~h}$ ) to the day prior to the observation of P4 concentrations less than $1 \mathrm{ng} / \mathrm{mL}$. Using this definition, a lifespan of the $\mathrm{CL} \geq 16$ days was classified as normal-function and $<16$ days as premature regression [3]. Non-functional CLs were defined in the present study when the length of the luteal phase was zero days since in this category P4 concentrations were below $1 \mathrm{ng} / \mathrm{mL}$ in all evaluations.

\subsection{Analysis of the images obtained}

The diameter (mean of two measurements) and area were obtained in the ultrasonographic image that visually represented the largest size of the CL. In the case of CLs with a cavity, the latter was measured and subtracted to obtain the area of luteal tissue.

A B-mode image of each CL was used to quantify the number of pixels for the evaluation and comparison of echogenicity and echotexture. This analysis was carried out in four regions of each luteal structure using the Image Pro Plus ${ }^{\circledR}$ software (Media Cybernetics, Inc., San Diego, CA, USA). A minimum representative area was defined for this analysis according to Viana et al. [20] and the mean numerical pixel value (NPV) and pixel heterogeneity (standard deviation of NPV) were determined. CLs with a size smaller than the minimum representative area were sampled by the largest representative area.

The color Doppler images were used to evaluate vascular areas in the luteal structures. For this purpose, images of greatest CL vascularization were selected and the vascular area was calculated using the Image $\mathrm{J}^{\mathbb{R}}$ software (National Institutes of Health, Bethesda, MD, USA). The percentage of vascularized CL (color Doppler area/total CL area $\times 100$ ) was then determined for each day 
of evaluation.

The following blood flow indices of the ovarian artery (measured at a site near the ovary containing the $\mathrm{CL}$ ) were obtained by spectral Doppler ultrasonography: peak systolic velocity (PSV), end diastolic velocity (EDV), vascular resistance (RI = [PSV-EDV]/ $\mathrm{PSV})$, and pulsatility index (PI $=[\mathrm{PSV}-\mathrm{EDV}] /$ mean velocity).

\subsection{Blood collection and measurement of serum progesterone concentration}

Blood samples were collected by puncture of the coccygeal vein, starting 4 days after GnRH application, into vacutainer tubes without additives, identified with the number of the animal and date of collection. After collection, the tubes were centrifuged at $2500 \times g$ for $15 \mathrm{~min}$. The serum obtained was divided into two equal aliquots, transferred to properly identified polypropylene microcentrifuge tubes, and stored at $-20^{\circ} \mathrm{C}$. The concentrations of P4 were quantified by solid-phase radioimmunoassay using a specific kit (Progesterone Ref: IM1188, Immunotech, Beckmann Coulter Co. Pasadena, CA, USA) in the Laboratory of Animal Endocrinology, FMVA-UNESP, Araçatuba. Three assays were performed and the inter- and intra-assay coefficients of variation were $4.9 \%$ and $7.3 \%$, respectively, with a mean sensitivity of $0.318 \mathrm{ng} / \mathrm{mL}$.

\subsection{Statistical analysis}

The variables follicular diameter on the day of GnRH application, number of CLs formed, length of the luteal phase, and consequent $\mathrm{CL}$ function (normal-function, prematurely regressed or nonfunctional) were analyzed with the GENMOD procedure of the SAS 9.2 program (SAS Institute, Inc., Cary, NC). The means of each variable were compared between treatments and between $\mathrm{CL}$ categories in each treatment, as well as their interactions. A Poisson distribution was considered for the number of CLs formed, length of the luteal phase and CL function, while a normal frequency distribution was assumed for follicular diameter on the day of GnRH application.

Corpus luteum diameter and area, mean NPV, pixel heterogeneity, percentage of $\mathrm{CL}$ vascularization, vascular indices of the ovarian artery (PSV, EDV, RI, and PI), and P4 concentration were analyzed using the MIXED procedure of the same statistical program, considering repeated measures over time (evaluations). The mean values of the parameters were compared between treatments, CL categories and days of evaluation, as well as the interactions treatment $v s$. day of evaluation, treatment $v$ s. luteal function and treatment $v s$. luteal function $v s$. day of evaluation.

Log10 transformation was applied to the variables PSV, EDV, PI and P4 concentration and square root transformation to area and percentage of $\mathrm{CL}$ vascularization. The concentration of $\mathrm{P} 4$ was correlated with area and percentage of $\mathrm{CL}$ vascularization using Pearson's correlation test. The relationship between variables was analyzed with the GLM procedure to determine the variable that best contributes to the study. Differences were considered significant when $\mathrm{p} \leq 0.05$.

\section{Results}

Three categories of CL function were defined based on the length of the luteal phase found in the present study: 1) normalfunction (NF) - length of the luteal phase $\geq 16$ days; 2 ) prematurely regressed $(\mathrm{PR})-$ length of the luteal phase $<16$ days, and 3 ) non-functional (NonF) - zero days of the luteal phase (despite the morphological presence of the $\mathrm{CL}$ ) due to $\mathrm{P} 4$ concentrations less than $1 \mathrm{ng} / \mathrm{mL}$ on all days of evaluation. In GP4+GnRH, 80.77\% (21/ 26) of the CLs were normal-function CLs and 19.23\% (5/26) prematurely regressed. In GGnRH, there were 4.0\% (1/25) normalfunction CLs, $44.0 \%$ (11/25) prematurely regressed CLs, and $52.0 \%$ (13/25) non-functional CLs.

The mean follicular diameter on the day of GnRH application differed between treatments $(\mathrm{p}=0.03)$ and was $12.42 \pm 0.40 \mathrm{~mm}$ in $\mathrm{GP} 4+\mathrm{GnRH}$ and $10.88 \pm 0.57 \mathrm{~mm}$ in GGnRH. However, no difference $(p=0.22)$ was observed when follicular diameter was compared between CL categories in the same treatment (Table 1).

Some CLs (39/55, 70.91\%) were observed $48 \mathrm{~h}$ after GnRH application and the presence of all CLs that developed in response to treatment was confirmed $96 \mathrm{~h}$ after GnRH application in both treatments. Six (10.53\%) of the 57 animals, three in each group, did not respond to the hormone treatment applied, as demonstrated by the absence of a CL up to $96 \mathrm{~h}$ after GnRH administration, corresponding to an ovulation rate of $89.66 \%(26 / 29)$ in heifers of GP4+GnRH and of 89.29\% (25/28) in those of GGnRH.

The number of CLs formed did not differ between treatments $(\mathrm{p}=0.86)$ or between $\mathrm{CL}$ categories in the same treatment $(\mathrm{p}=0.87)$. The formation of two CLs was observed in only one animal of treatment GP4+GnRH $(1 / 26=3.85 \%)$, while in GGnRH two animals developed two CLs $(2 / 25=8.0 \%)$ and one developed three CLs $(1 / 25=4.0 \%)$. Each CL was used as a sampling unit. The two CLs observed in the heifer of GP4+GnRH had a normalfunction and the CLs of heifers of GGnRH regressed prematurely.

A difference in the length of the luteal phase was observed between treatments $(p<0.0001)$ and between $C L$ categories in the same treatment $(\mathrm{p}<0.0001)$ (Table 1$)$. Although it was not possible to determine the length of the luteal phase for CLs classified as nonfunctional, most of these structures morphologically persisted for

Table 1

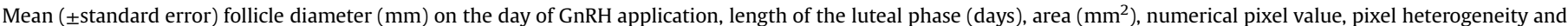

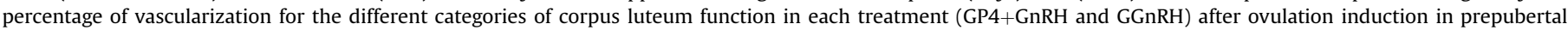
Nellore heifers.

\begin{tabular}{|c|c|c|c|c|c|c|}
\hline & \multicolumn{2}{|l|}{ GP4+GnRH } & \multicolumn{3}{|l|}{ GGnRH } & \multirow[t]{2}{*}{$\mathrm{p}$ - value } \\
\hline & $\begin{array}{l}\mathrm{NF} \\
(\mathrm{n}=21)\end{array}$ & $\begin{array}{l}\text { PR } \\
(n=5)\end{array}$ & $\begin{array}{l}\text { NF } \\
(n=1)\end{array}$ & $\begin{array}{l}P R \\
(n=11)\end{array}$ & $\begin{array}{l}\text { NonF } \\
(n=13)\end{array}$ & \\
\hline Follicular diameter (mm) & $11.79 \pm 0.37^{\mathrm{a}}$ & $13.05 \pm 0.70^{\mathrm{a}}$ & $12.13 \pm 1.57^{\mathrm{ab}}$ & $10.53 \pm 0.47^{b}$ & $9.98 \pm 0.44^{\mathrm{b}}$ & 0.22 \\
\hline Luteal phase (days) ${ }^{*}$ & $17.81 \pm 0.05^{\mathrm{a}}$ & $11.60 \pm 0.13^{\mathrm{b}}$ & $22.00 \pm 0.21^{\mathrm{a}}$ & $9.27 \pm 0.10^{b}$ & $0.00 \pm 0.01^{c}$ & $<0.0001$ \\
\hline $\mathrm{CL}$ area $\left(\mathrm{mm}^{2}\right)$ & $112.05 \pm 8.24^{\mathrm{a}}$ & $78.40 \pm 13.84^{\mathrm{b}}$ & $154.38 \pm 22.85^{\mathrm{a}}$ & $58.33 \pm 10.72^{\mathrm{b}}$ & $31.89 \pm 11.46^{\mathrm{c}}$ & $<0.0001$ \\
\hline NPV & $92.66 \pm 2.03^{\mathrm{b}}$ & $92.48 \pm 3.22^{\mathrm{b}}$ & $105.70 \pm 4.91^{\mathrm{a}}$ & $88.93 \pm 2.60^{\mathrm{bc}}$ & $84.05 \pm 2.90^{c}$ & 0.002 \\
\hline Heterogeneity & $12.00 \pm 0.19^{\mathrm{ac}}$ & $12.03 \pm 0.33^{\mathrm{ac}}$ & $13.28 \pm 0.51^{\mathrm{a}}$ & $11.11 \pm 0.35^{\mathrm{bc}}$ & $11.59 \pm 0.40^{\mathrm{ac}}$ & 0.008 \\
\hline CL vascularization (\%) & $20.85 \pm 1.18^{\mathrm{a}}$ & $15.73 \pm 2.14^{\mathrm{b}}$ & $18.12 \pm 3.34^{\mathrm{ab}}$ & $13.64 \pm 2.27^{\mathrm{b}}$ & $10.88 \pm 2.59^{\mathrm{b}}$ & 0.05 \\
\hline
\end{tabular}

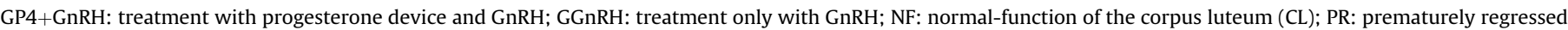
CL; NonF: non-functional CL; NPV: numerical pixel value; Heterogeneity: pixel heterogeneity (standard deviation).

$\mathrm{a}, \mathrm{b}, \mathrm{c}$ Means in the same row followed by different lowercase letters differ between CL categories and between treatments (Tukey test, $\mathrm{p} \leq 0.05$ ).

* The length of CL function was defined from $24 \mathrm{~h}$ after GnRH administration to the day prior to progesterone concentrations less than $1 \mathrm{ng} / \mathrm{mL}$. 
up to 12 days after GnRH application as shown in Fig. 2.

The diameter of the $\mathrm{CL}$ was influenced by the interaction of the three effects studied: treatment, CL category and day of evaluation $(p=0.04)$ (Fig. 2-A). At the beginning of the evaluations, a difference was only observed between normal-function CLs of $\mathrm{GP} 4+\mathrm{GnRH}$ and non-functional CLs of GGnRH, with the former

(A)

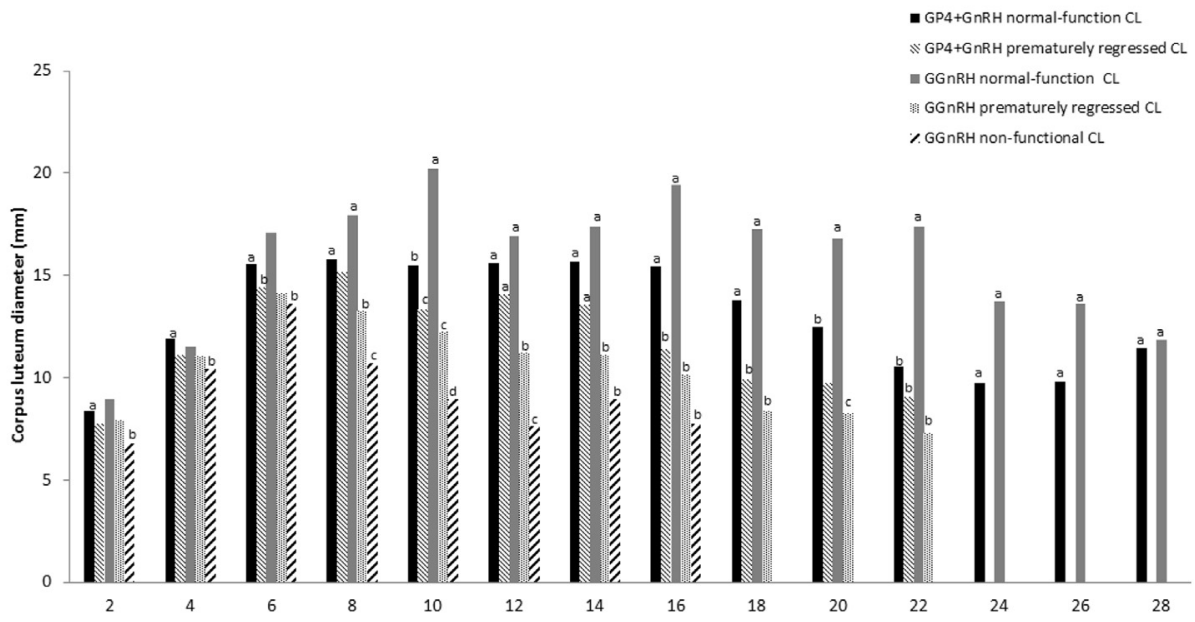

(B)

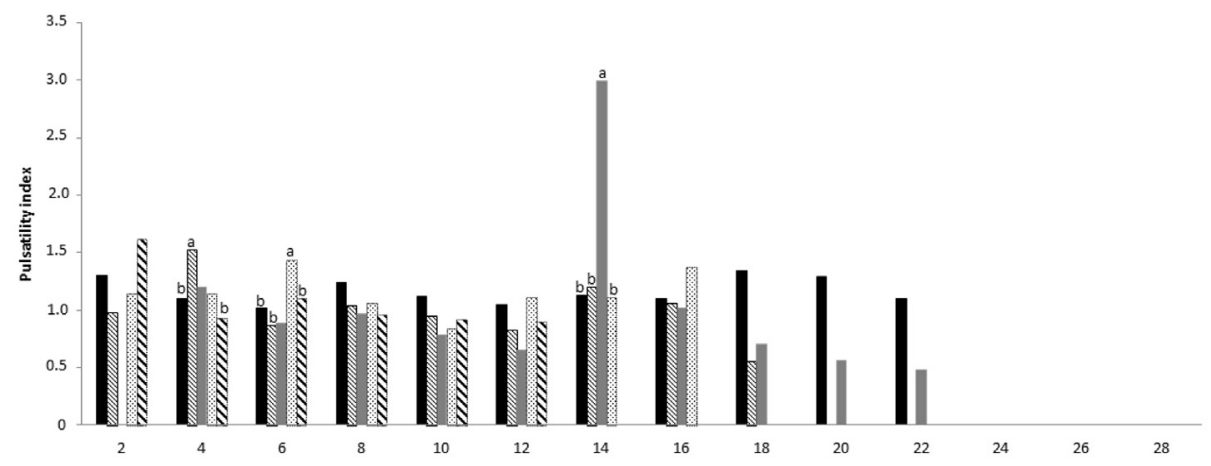

(C)

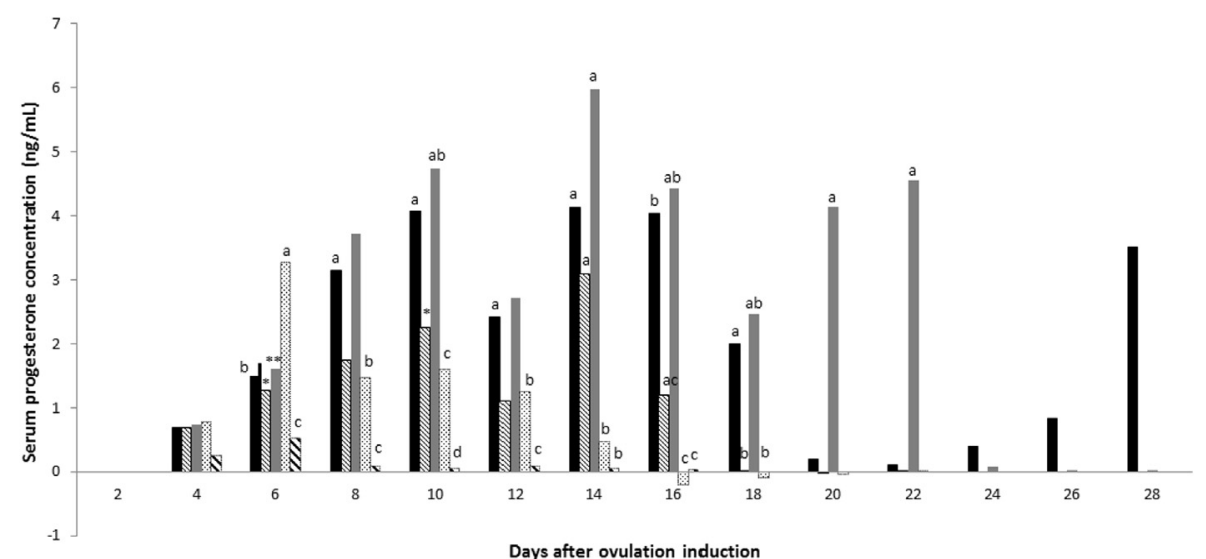

Frequency (n)

\begin{tabular}{ccccccccccccccc}
\hline \multirow{2}{*}{ GP4+GnRH } & NF & 13 & 22 & 22 & 22 & 22 & 22 & 22 & 22 & 22 & 21 & 16 & 8 & 3 \\
& PR & 5 & 5 & 5 & 5 & 5 & 5 & 4 & 4 & 4 & 1 & 1 & 1 \\
\hline \multirow{3}{*}{ GGnRH } & NF & 1 & 1 & 1 & 1 & 1 & 1 & 1 & 1 & 1 & 1 & 1 & 1 & 1 \\
& PR & 12 & 15 & 15 & 15 & 14 & 14 & 8 & 8 & 6 & 2 & 1 & & \\
& NonF & 12 & 13 & 13 & 13 & 13 & 12 & 1 & 1 & & & & \\
\end{tabular}

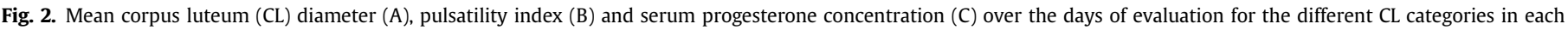

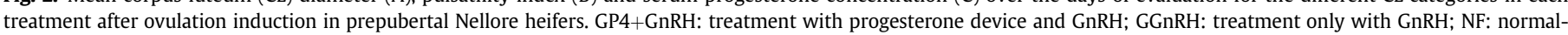
function of the CL; PR: prematurely regressed CL; NonF: non-functional CL; n: number of animals per evaluation day in each group.

$\mathrm{a}, \mathrm{b}, \mathrm{c}, \mathrm{d}$ Different lowercase letters indicate differences between groups on the same day of evaluation (Tukey test, $\mathrm{p} \leq 0.05)$. ${ }^{*} \mathrm{bc}{ }^{* *} \mathrm{abc}$ 
always exhibiting a greater diameter than the latter. At the end of the evaluations, the diameters of the different CL categories were similar, irrespective of treatment.

No interaction between the three effects was identified for CL area $(\mathrm{p}=0.07)$, only between treatment and CL category $(\mathrm{p}<0.0001)$ (Table 1) and over the days of evaluation $(\mathrm{p}<0.0001)$ (Table 2). The area of normal-function and prematurely regressed CLs was similar in the GP4+GnRH and GGnRH treatments, with normal-function CLs exhibiting a greater area. The area of nonfunctional CLs was smaller compared to the other two CL categories. An increase in CL area was observed at the beginning of the luteal phase, which reached its peak on day 6 after ovulation induction, followed by a gradual daily decrease until the end of the luteal phase, when the values were similar to the initial values.

There was no interaction between treatment, CL category and day of evaluation for mean NPV or pixel heterogeneity $(p=0.44$ and $\mathrm{p}=0.38$, respectively). However, differences in the two parameters were observed for the treatment $v s$. CL category interaction ( $\mathrm{p}=0.002$ and $\mathrm{p}=0.008$, respectively) (Table 1 ). Normalfunction CLs of GGnRH and normal-function and prematurely regressed CLs of GP4+GnRH exhibited higher NPV, while lower values were observed for prematurely regressed and nonfunctional CLs of GGnRH. For pixel heterogeneity, a difference was also observed over the days of evaluation ( $p<0.001$ ) (Table 2 ), with higher values at the beginning and end of the luteal phase.

Vascularization of the CL was not influenced by the interaction of treatment, CL category and day of evaluation $(\mathrm{p}=0.44)$. Differences were observed for the treatment $v s$. CL category interaction $(p=0.05)$ (Table 1$)$ and over the days of evaluation $(p=0.02)$ (Table 2). The percentage of vascularization was higher in normalfunction CLs of GP4+GnRH and similar between the other categories. Higher percentages were observed at the beginning of evaluation, with values higher than $20 \%$ up to day 14 after ovulation induction, and lower percentages at the end of the luteal phase, with a marked decrease between days 20 and 22 .

The blood flow indices of the ovarian artery were determined until day 22 after ovulation induction. After this day, it was difficult to measure these parameters because the CL was already poorly vascularized. Peak systolic velocity, EDV or RI was not influenced by the interaction of treatment, CL category and day of evaluation ( $\mathrm{p}=0.77, \mathrm{p}=0.28$ and $\mathrm{p}=0.18$, respectively), nor by the treatment vs. $\mathrm{CL}$ category interaction $(\mathrm{p}=0.56, \mathrm{p}=0.78$ and $\mathrm{p}=0.13$, respectively). Peak systolic velocity and EDV differed throughout the days of evaluation ( $\mathrm{p}=0.02$ and $\mathrm{p}=0.03$, respectively)
Table 3

Mean ( \pm standard error) end diastolic velocity and resistivity index over the days of evaluation (D2-22) in each treatment (GP4+GnRH and GGnRH) after ovulation induction in prepubertal Nellore heifers.

\begin{tabular}{|c|c|c|c|}
\hline Evaluation & Treatment & $\mathrm{EDV}(\mathrm{cm} / \mathrm{sec})$ & RI \\
\hline D2 & $\begin{array}{l}\text { GP4+GnRH }(\mathrm{n}=18) \\
\text { GGnRH }(\mathrm{n}=25)\end{array}$ & $\begin{array}{l}5.71 \pm 1.56^{\mathrm{aDE}} \\
4.44 \pm 2.07^{\mathrm{aF}}\end{array}$ & $\begin{array}{l}0.63 \pm 0.04^{\mathrm{aAB}} \\
0.67 \pm 0.05^{\mathrm{aAB}}\end{array}$ \\
\hline D4 & $\begin{array}{l}\text { GP4+GnRH }(n=27) \\
\text { GGnRH }(n=29)\end{array}$ & $\begin{array}{l}9.11 \pm 0.99^{\mathrm{aCE}} \\
7.42 \pm 1.11^{\mathrm{aEF}}\end{array}$ & $\begin{array}{l}0.61 \pm 0.03^{\mathrm{aAB}} \\
0.60 \pm 0.03^{\mathrm{aBC}}\end{array}$ \\
\hline D6 & $\begin{array}{l}\text { GP4+GnRH }(n=27) \\
\text { GGnRH }(n=29)\end{array}$ & $\begin{array}{l}10.15 \pm 0.99^{\mathrm{aBCE}} \\
9.08 \pm 1.11^{\mathrm{aCDE}}\end{array}$ & $\begin{array}{l}0.56 \pm 0.03^{\mathrm{aB}} \\
0.67 \pm 0.03^{\mathrm{bA}}\end{array}$ \\
\hline D8 & $\begin{array}{l}\text { GP4+GnRH }(n=27) \\
\text { GGnRH }(n=29)\end{array}$ & $\begin{array}{l}9.86 \pm 0.99^{\mathrm{aBCE}} \\
12.58 \pm 1.11^{\mathrm{aABD}}\end{array}$ & $\begin{array}{l}0.63 \pm 0.03^{\mathrm{aA}} \\
0.60 \pm 0.03^{\mathrm{aBC}}\end{array}$ \\
\hline D10 & $\begin{array}{l}\text { GP4+GnRH }(n=27) \\
\text { GGnRH }(n=28)\end{array}$ & $\begin{array}{l}11.30 \pm 0.99^{\mathrm{aABC}} \\
11.52 \pm 1.22^{\mathrm{aBCD}}\end{array}$ & $\begin{array}{l}0.61 \pm 0.03^{\mathrm{aAB}} \\
0.54 \pm 0.03^{\mathrm{aC}}\end{array}$ \\
\hline D12 & $\begin{array}{l}\text { GP4+GnRH }(\mathrm{n}=27) \\
\text { GGnRH }(\mathrm{n}=26)\end{array}$ & $\begin{array}{l}12.83 \pm 1.01^{\mathrm{aA}} \\
10.34 \pm 1.32^{\mathrm{aBCDE}}\end{array}$ & $\begin{array}{l}0.59 \pm 0.03^{\mathrm{aAB}} \\
0.59 \pm 0.03^{\mathrm{aBC}}\end{array}$ \\
\hline D14 & $\begin{array}{l}\text { GP4+GnRH }(n=26) \\
\text { GGnRH }(n=10)\end{array}$ & $\begin{array}{l}12.29 \pm 1.01^{\mathrm{aAB}} \\
8.65 \pm 2.02^{\mathrm{aBCDEF}}\end{array}$ & $\begin{array}{l}0.58 \pm 0.03^{\mathrm{aAB}} \\
0.65 \pm 0.05^{\mathrm{aABC}}\end{array}$ \\
\hline D16 & $\begin{array}{l}\text { GP4+GnRH }(n=26) \\
\text { GGnRH }(n=10)\end{array}$ & $\begin{array}{l}12.14 \pm 1.03^{\mathrm{aAB}} \\
7.78 \pm 2.43^{\mathrm{aDEF}}\end{array}$ & $\begin{array}{l}0.59 \pm 0.03^{\mathrm{aAB}} \\
0.68 \pm 0.06^{\mathrm{aAB}}\end{array}$ \\
\hline D18 & $\begin{array}{l}\text { GP4+GnRH }(\mathrm{n}=26) \\
\mathrm{GGnRH}(\mathrm{n}=7)\end{array}$ & $\begin{array}{l}10.20 \pm 1.23^{\mathrm{aABCE}} \\
16.48 \pm 4.94^{\mathrm{aABCDE}}\end{array}$ & $\begin{array}{l}0.64 \pm 0.03^{\mathrm{aA}} \\
0.50 \pm 0.12^{1 \mathrm{aBC}}\end{array}$ \\
\hline D20 & $\begin{array}{l}\text { GP4+GnRH }(n=23) \\
\text { GGnRH }(n=3)\end{array}$ & $\begin{array}{l}8.04 \pm 1.59^{\mathrm{aCDE}} \\
18.64 \pm 4.98^{\mathrm{bABC}}\end{array}$ & $\begin{array}{l}0.65 \pm 0.04^{\mathrm{aA}} \\
0.43 \pm 0.13^{\mathrm{aABC}}\end{array}$ \\
\hline D22 & $\begin{array}{l}\text { GP4+GnRH }(n=17) \\
\text { GGnRH }(n=2)\end{array}$ & $\begin{array}{l}5.38 \pm 2.80^{\mathrm{aE}} \\
21.81 \pm 4.98^{\mathrm{bA}}\end{array}$ & $\begin{array}{l}0.63 \pm 0.07^{\mathrm{aAB}} \\
0.41 \pm 0.13^{\mathrm{aBC}}\end{array}$ \\
\hline
\end{tabular}

GP4+GnRH: treatment with progesterone device and GnRH; GGnRH: treatment only with GnRH; EDV: end diastolic velocity; RI: resistivity index.

$a$,b Means in the same column followed by different lowercase letters differ between treatments on the same day of evaluation (Tukey test, $\mathrm{p} \leq 0.05$ ).

$\mathrm{A}, \mathrm{B}, \ldots \mathrm{F}$ Means in the same column followed by different uppercase letters differ over the days of evaluation in the same treatment (Tukey test, $\mathrm{p} \leq 0.05$ ).

(Table 2). Peak systolic velocity increased gradually until the midluteal phase and remained constant until the end of the luteal phase.

A difference in EDV, as well as in RI, was also observed for the treatment $v s$. day of evaluation interaction $(\mathrm{p}=0.04$ for both variables) (Table 3). For EDV, differences between treatments were only found in the last two assessments, with higher values in GGnRH. The RI differed between treatments in only one assessment (day 6 after ovulation induction). A greater difference could be seen

Table 2

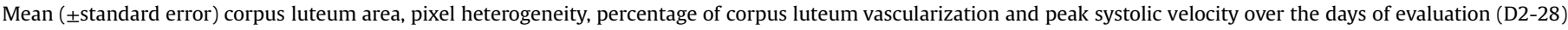
after ovulation induction in prepubertal Nellore heifers.

\begin{tabular}{|c|c|c|c|c|}
\hline Day of evaluation & $\begin{array}{l}\text { CL area } \\
\left(\mathrm{mm}^{2}\right)\end{array}$ & Heterogeneity & CL vascularization (\%) & $\begin{array}{l}\text { PSV } \\
(\mathrm{cm} / \mathrm{sec})\end{array}$ \\
\hline D2 $(n=43)$ & $60.89 \pm 7.04^{\mathrm{FH}}$ & $13.61 \pm 0.30^{A}$ & $23.67 \pm 1.85^{\mathrm{ABE}}$ & $15.31 \pm 2.56^{\mathrm{D}}$ \\
\hline $\mathrm{D} 4(\mathrm{n}=56)$ & $107.95 \pm 6.68^{\mathrm{E}}$ & $13.10 \pm 0.30^{\mathrm{B}}$ & $23.80 \pm 1.56^{\mathrm{AB}}$ & $21.77 \pm 1.51^{\mathrm{C}}$ \\
\hline D6 $(n=56)$ & $169.11 \pm 6.72^{\mathrm{A}}$ & $12.35 \pm 0.26^{\mathrm{BC}}$ & $25.98 \pm 1.55^{\mathrm{A}}$ & $25.62 \pm 1.51^{\mathrm{B}}$ \\
\hline $\mathrm{D} 8(\mathrm{n}=56)$ & $153.38 \pm 6.74^{\mathrm{B}}$ & $11.88 \pm 0.26^{\mathrm{C}}$ & $22.60 \pm 1.56^{\mathrm{ABE}}$ & $29.69 \pm 1.51^{\mathrm{A}}$ \\
\hline D10 $(n=55)$ & $146.14 \pm 6.76^{\mathrm{BC}}$ & $11.63 \pm 0.26^{C}$ & $20.48 \pm 1.59^{\mathrm{BCE}}$ & $27.66 \pm 1.58^{\mathrm{AB}}$ \\
\hline $\mathrm{D} 12(\mathrm{n}=54)$ & $140.22 \pm 6.78^{\mathrm{CD}}$ & $11.92 \pm 0.27^{C}$ & $22.09 \pm 1.62^{\mathrm{ABE}}$ & $28.89 \pm 1.67^{\mathrm{AB}}$ \\
\hline $\mathrm{D} 14(\mathrm{n}=36)$ & $141.42 \pm 7.79^{\mathrm{BD}}$ & $11.60 \pm 0.35^{C}$ & $20.80 \pm 2.04^{\mathrm{BCE}}$ & $27.60 \pm 2.23^{\mathrm{AB}}$ \\
\hline $\mathrm{D} 16(\mathrm{n}=36)$ & $130.35 \pm 8.02^{\mathrm{D}}$ & $11.32 \pm 0.35^{C}$ & $16.18 \pm 2.12^{\mathrm{CDEF}}$ & $27.46 \pm 2.61^{\mathrm{AB}}$ \\
\hline D18 $(\mathrm{n}=33)$ & $106.99 \pm 8.53^{\mathrm{E}}$ & $11.63 \pm 0.40^{\mathrm{BC}}$ & $13.50 \pm 2.60^{\mathrm{DEFG}}$ & $30.06 \pm 4.98^{\mathrm{ABC}}$ \\
\hline $\mathrm{D} 20(\mathrm{n}=26)$ & $93.64 \pm 11.30^{\mathrm{EG}}$ & $11.67 \pm 0.56^{\mathrm{ABC}}$ & $12.58 \pm 3.23^{\mathrm{DEFG}}$ & $28.53 \pm 5.20^{\mathrm{ABC}}$ \\
\hline $\mathrm{D} 22(\mathrm{n}=19)$ & $82.57 \pm 13.96^{\mathrm{EF}}$ & $10.23 \pm 0.68^{C}$ & $9.10 \pm 3.95^{\mathrm{DEFG}}$ & $26.26 \pm 5.68^{\mathrm{ABCD}}$ \\
\hline $\mathrm{D} 24(\mathrm{n}=9)$ & $44.57 \pm 19.31^{\mathrm{H}}$ & $11.88 \pm 0.98^{\mathrm{ABC}}$ & $4.69 \pm 5.72^{\mathrm{FG}}$ & - \\
\hline $\mathrm{D} 26(\mathrm{n}=4)$ & $45.74 \pm 22.51^{\mathrm{FH}}$ & $13.13 \pm 1.06^{\mathrm{ABC}}$ & $3.35 \pm 6.18^{G}$ & - \\
\hline $\mathrm{D} 28(\mathrm{n}=2)$ & $51.39 \pm 27.10^{\mathrm{FGH}}$ & $12.10 \pm 1.29^{\mathrm{ABC}}$ & $8.70 \pm 7.48^{\mathrm{EFG}}$ & - \\
\hline
\end{tabular}

PSV: peak systolic velocity.

$\mathrm{A}, \mathrm{B}, \mathrm{C}, \ldots \mathrm{H}$ Means in the same column followed by different uppercase letters differ over the days of evaluation (Tukey test, $\mathrm{p} \leq 0.05$ ). 
at the end of the luteal phase in GGnRH, with numerically lower RI values compared to GP4+GnRH.

The ovarian artery PI $(\mathrm{p}=0.008)$ (Fig. 2-B) and serum P4 concentration ( $p=0.03$ ) (Fig. $2-C$ ) were influenced by the interaction between the three effects studied. In two early assessments (days 4 and 6 after ovulation induction), a higher PI was observed for prematurely regressed CLs in both treatments (GP4+GnRH and $\mathrm{GGnRH}$ ). At the end of the luteal phase, in one assessment (day 14 after ovulation induction) the PI was higher for normal-function CLs of GGnRH. No differences were observed between treatments or CL categories for the remaining evaluations.

Serum P4 concentrations differed significantly between CL categories throughout the days of evaluation, with the observation of higher concentrations in normal-function CLs of both treatments, intermediate levels in prematurely regressed CLs, and levels always less than $1 \mathrm{ng} / \mathrm{mL}$ in non-functional CLs. Concentration of P4 was positively correlated with $\mathrm{CL}$ area $(\mathrm{r}=0.62 ; \mathrm{p}<0.001)$ and percentage of $C L$ vascularization $(r=0.38 ; p<0.001)$. A low correlation was observed between follicular diameter and CL category $\left(R^{2}=0.15\right), C L$ category and P4 concentration $\left(R^{2}=0.19\right), C L$ category and vascularization percentage $\left(R^{2}=0.10\right)$, and $C L$ area and vascularization percentage $\left(R^{2}=0.13\right)$. The area of the $C L$ was the variable that showed the highest correlation with $\mathrm{P} 4$ concentration $\left(\mathrm{R}^{2}=0.53\right)$, resulting in the following regression equation: $\mathrm{CL}$ area $=91.75+37.68 \mathrm{P} 4-2.86 \mathrm{P} 4^{2}$.

\section{Discussion}

The expected ovulation rate of heifers using a dose of $0.01 \mathrm{mg}$ buserelin acetate for ovulation induction ranges from 50 to $60 \%$ [21]. The high ovulation rate found in the present study for both treatments is probably due to the high dose of the ovulation inducer applied. Higher rates were expected for the group receiving an exogenous source of $\mathrm{P} 4$ because of persistence of the follicle during maintenance of the P4 device in the animal, which would have a greater diameter on the day of application of the ovulation inducer. The high dose and application on a random day of the estrous cycle in the group treated only with GnRH may have induced the ovulation of very young follicles, resulting in a high incidence of premature regression and non-functional CLs. The experimental models used were found to be efficient in inducing normal-function and prematurely regressed CLs in both treatments and exposure to P4 reduced the occurrence of premature regression.

Exposure of heifers to P4 before the first estrous cycle has beneficial effects on the preovulatory follicle $[22,23]$ and on CL function [24,25]. Progesterone reduces the negative feedback caused by excess estradiol receptors in the hypothalamus [26], increasing the release of gonadotrophins (FSH and $\mathrm{LH}$ ) by the pituitary and, consequently, the growth rate of the dominant follicle $[22,27]$. This fact is confirmed in the present study by the greater diameter of the preovulatory follicle observed in GP4+GnRH. The beneficial effect on $\mathrm{CL}$ function is related to the fact that P4 inhibits oxytocin receptors in the endometrium after ovulation, preventing the premature release of prostaglandin $\mathrm{F}_{2 \alpha}\left(\mathrm{PGF}_{2 \alpha}\right)$ by the uterine endometrium. Consequently, regression of the $\mathrm{CL}$ is not stimulated before the physiological time [25]. According to Sá Filho et al. $[28,29]$ and Pfeifer et al. [22], previous exposure to P4 prolongs persistence of the CL and improves pregnancy/artificial insemination rates.

In the present study, prematurely regressed CLs persisted for 9-12 days. A similar CL lifespan has been reported by Sharma et al. [30] who found a variation of 8-12 days by ultrasonography. Shorter lifespans were observed by Evans et al. [27] and Sá Filho et al. [28]. Evans et al. [27] reported an average lifespan of the CL of
7 days accompanied by the wave of follicular development, and Sá Filho et al. [28] observed a decline in P4 concentrations by day 5 after ovulation induction.

One CL category established in the present study was nonfunctional. These CLs exhibited a vascularization percentage and follicular diameter on the day of GnRH application similar to prematurely regressed CLs of the same group, but had a smaller area. This smaller area results in a smaller number of luteal cells, a fact that was possible responsible for the lower concentration of P4 produced by these CLs in the present study. Non-functional CLs may also be a consequence of inadequate exposure of the follicles to gonadotrophins before ovulation [31], ovulation of these still young follicles [4], and/or failure in vascular development both in the preovulatory follicle and at the onset of CL formation [32]. A known alteration that could explain the low production of P4 by nonfunctional CLs is luteal dysfunction, which is characterized by inadequate function of the CL and deficient secretion of P4 [33]. These data show that, in addition to a higher probability of premature regression, the first $\mathrm{CL}$ formed in prepubertal heifers without previous exposure to P4 may be non-functional. It should be noted that non-functional CLs were identified in the present study by ovarian ultrasonography and remained in the ovary for a similar period as prematurely regressed CLs.

The diameter and area of the $\mathrm{CL}$ differed between the functional categories established in the present study. Normal-function CLs had a greater diameter and area, CLs that regressed prematurely exhibited intermediate values, and non-functional CLs had a smaller diameter and area. These results can be explained by the diameter of the dominant follicle found on the day of GnRH application, as demonstrated by the studies of Borges et al. [34], Pugliesi et al. [35] and Vasconcelos et al. [36]. The measurement of CL diameter might be a suitable tool that can be used in the field for the diagnosis of non-functional CLs since this category exhibited smaller diameters 8 days after ovulation induction, with values less than $10 \mathrm{~mm}$ in most evaluations.

Pixels represent the echogenicity of a tissue, which corresponds to the intensity of the reflected sound wave at a specific site of the tissue. The pixel value in a grayscale image ranges from 0 (black, anechoic image) to 255 (white, hyperechoic image) [37]. According to Davies et al. [38], higher pixel values indicate greater organization and density of luteal cells. In the present study, lower pixel values were observed for non-functional CLs, probably because they possess lower tissue organization compared to the other categories.

The pixel heterogeneity values, which represent the echotexture of a tissue, agree with those reported by Siqueira et al. [18] and Simões et al. [39], with the observation of higher values at the beginning and end of the luteal phase. This finding is probably due to the cell differentiation that occurs in the CL during these stages. At the beginning of the luteal phase, the number of luteal cells is small and, since the CL is developing, the ultrasound image is heterogenous. The same is observed at the end of the luteal phase as a result of cell death and tissue degradation that occur in the CL due to luteolysis $[18,40]$.

Color Doppler ultrasonography permits the real-time evaluation of $C L$ vascularization, which is an advantage in field studies for the diagnosis of CL function since it is a noninvasive and rapid tool [9]. Variations in the vascularization pattern of this structure occur across the estrous cycle, with an increase in blood flow during luteogenesis and a reduction during luteolysis [9,11], which was observed in the present study. The increased blood flow during luteogenesis is the results of intense angiogenesis and vasodilation that occur at the site [41], while the reduced flow during luteolysis is due to the pulsatile release of $\mathrm{PGF}_{2 \alpha}$ by the endometrium. $\mathrm{PGF}_{2 \alpha}$ induces the release of vasoactive peptides that mediate 
vasoconstriction of blood vessels and consequently reduce blood flow to the CL [42].

Vascularization of the $\mathrm{CL}$ is directly related to tissue function [43]. Thus, a higher vascularization percentage was observed in the present study for normal-function CLs of the treatment with previous exposure to P4 compared to prematurely regressed and nonfunctional CLs. This finding highlights the importance of adequate blood supply during the formation and development of the $\mathrm{CL}$ $[9,11]$. The lower vascularization percentage found for nonfunctional CLs may have contributed to the low P4 concentrations produced by these structures. The decrease in the Doppler signal as an exclusion criterion of animals from the evaluations was efficient in establishing $\mathrm{CL}$ function since the P4 concentrations remained below $1 \mathrm{ng} / \mathrm{mL}$ after this day.

Studies have shown promising results with the use of color Doppler ultrasonography for the early diagnosis of pregnancy in cattle by means of visual evaluation of CL vascularization $[44,45]$. This technique is also used in embryo transfer programs for the evaluation of $\mathrm{CL}$ vascularization before the transfer procedure $[46,47]$. Guimarães et al. [46] found that visual evaluation of blood flow in the CL 14 days after embryo transfer is efficient in detecting non-pregnant recipient females submitted to the embryo transfer protocol. The use of Doppler ultrasonography facilitates management decisions on a farm such as the selection of animals to be kept in the herd, increasing the chance of reproductive success and diagnosis of pregnancy [47]. Another application of this technique is the prediction of luteal function, as done in the present study.

The production of $\mathrm{P} 4$ by the $\mathrm{CL}$ varies along its persistence in the ovary [11], a fact that is related to the vascularization of this structure $[40,41,48]$. An increase in the secretion of this hormone is observed during luteogenesis $[15,18]$ and the opposite occurs during luteolysis [49]. In the present study, serum P4 concentration was efficient in diagnosing CL function since the levels of this hormone differed significantly between non-functional CLs and the other categories 6 days after ovulation induction and after 8 days when compared to prematurely regressed CLs. This difference continued in most evaluations. However, since the result of this analysis is not immediate, its application in the field is difficult.

The present study found a stronger positive correlation of serum P4 concentration with $\mathrm{CL}$ area than with vascularization percentage, in contrast to Herzog et al. [16]. In the studies of Mann [15], Siqueira et al. [18] and Vasconcelos et al. [36], CLs with a larger area were associated with higher circulating P4 concentrations.

The vascular indices measured by spectral Doppler, especially RI and PI, are used for the evaluation of stenosis, thrombosis and highresistance peripheral vessels [13]. This method permits to study the flow pattern of vessels in which changes can indicate physiological, systemic or local alterations. At the end of the estrous cycle, changes occur in the flow pattern of the intraovarian arteries, including an increase in resistance [12]. However, this was not observed in the present study for CLs of the GGnRH treatment. The decrease in RI values observed at the end of the evaluation period for CLs of GGnRH suggests a higher metabolism during luteolysis of these CLs, which was confirmed by the higher EDV at the end of the evaluations in this treatment. Analysis of the PI results showed that this index was the earliest variable for diagnosing premature regression since CLs of this category exhibited higher values 4-6 days after ovulation induction.

The results of the present study indicate the need for further studies to determine the causes of non-functional CLs in the first estrous cycle of prepubertal heifers and to compare morphological and functional characteristics with luteal structures of the second estrous cycle.

\section{Conclusion}

The present study demonstrated the importance of previous exposure of prepubertal heifers to progesterone as indicated by the higher percentage of CLs with normal-function in the first estrous cycle. Morphological and functional differences were observed between the CL categories established. Normal-function CLs exhibited a greater area compared to prematurely regressed and non-functional CLs. In the last category, luteal cells were less organized and less dense as demonstrated by the lower pixel values. The percentage of vascularization was higher in normalfunction CLs, while no difference in this parameter was observed between prematurely regressed and non-functional CLs. The low production of progesterone by non-functional CLs was not related to vascularization of this structure, but to the smaller area.

The present results indicate that serum progesterone concentration is efficient in diagnosing CL function. In addition to this variable, ovarian artery PI can be used for the early diagnosis of premature regression of the CL and ultrasonographic evaluation of CL diameter for the diagnosis of non-functional CLs. Serum progesterone concentration showed a higher correlation with $\mathrm{CL}$ area than with vascularization percentage. The relationship between $\mathrm{CL}$ area and P4 concentration best contributed to the study.

\section{Acknowledgements}

We thank FAPESP for financial support (Grant 2015/13079-0), Ouro Fino for kindly providing the products, and Centro APTA Bovinos de Corte (Instituto de Zootecnia, Sertãozinho-SP) for providing the animals and infrastructure for the study.

\section{References}

[1] Atkins JA, Pohler KG, Smith MF. Physiology and endocrinology of puberty in heifers. Vet Clin Food Anim 2013:29:479-93.

[2] Nogueira GP. Puberty in South America Bos indicus (Zebu) cattle. Anim Reprod Sci 2004;82:361-72.

[3] Garverick HA, Zollers WG, Smith MF. Mechanisms associated with corpus luteum lifespan in animals having normal or subnormal luteal function. Anim Reprod Sci 1992;28:111-24.

[4] Taponen J, Hjerppe P, Kopra E, Rodríguez-Martínez H, Katila T, Kindhl H. Premature prostaglandin $\mathrm{F}_{2}$ s secretion causes luteal regression in GnRHinduced short estrous cycles in cyclic dairy heifers. Theriogenology 2003;60: 379-93.

[5] Perry GA. Factors affecting puberty in replacement beef heifers. Theriogenology 2016;86:373-8.

[6] Viana JHM, Ferreira AM, Sá WF, Camargo LSA. Características morfológicas e funcionais do corpo lúteo durante o ciclo estral em vacas da raça Gir. Arq Bras Med Vet Zootec 1999:51:251-6.

[7] Siqueira LGB, Torres CAA, Viana JHM, Souza ED, Amorim LS, Fonseca JF, et al. Uso da análise computacional de imagens de ultra-som na avaliação da ecotextura luteal e sua relação com a concentração de progesterona plasmática durante o ciclo estral de novilhas mestiças (Bos taurus taurus x Bos taurus indicus). Acta Sci Vet 2007;35:1301.

[8] Siqueira LGB, Viana JHM, Diniz ES, Camargo LS, Amorim LS, Fonseca JF, et al. Aferição de ecogenicidade luteal com o uso de diferentes transdutores de ultra-som. Acta Sci Vet 2006;34:281

[9] Lüttgenau J, Bollwein H. Evaluation of bovine luteal blood flow by using color Doppler ultrasonography. Reprod Biol 2014;14:103-9.

[10] Sales JNS, Rosse GF, Bottino MP. Ultrassonografia do Sistema Reprodutor Feminino de Bovinos. In: Feliciano MAR, Oliveira MEF, Vicente WRR. Ultrassonografia na Reprodução Animal. São Paulo: MedVet; 2013. p. 105-25.

[11] Scully S, Evans ACO, Duffy P, Crowe MA. Characterization of follicle and CL development in beef heifers using high resolution three-dimensional ultrasonography. Theriogenology 2014;81:407-18.

[12] Köster K, Nautrup CP, Günzel-Apel AR. A Doppler ultrasonographic study of cyclic changes of ovarian perfusion in the Beagle bitch. Reprod 2001;3: 453-61.

[13] Carvalho CF, Chammas MC, Cerri GG. Princípios físicos do Doppler em ultrasonografia. Cienc Rural 2008:38:872-9.

[14] Ferreira AM. Reprodução da Fêmea Bovina: Fisiologia aplicada e Problemas mais comuns. first ed. Juiz de Fora: Editar; 2010. 
[15] Mann GE. Corpus luteum size and plasma progesterone concentration in cows. Anim Reprod Sci 2009;115:296-9.

[16] Herzog K, Brockhan-Lüdemann M, Kaske M, Beindorff N, Paul V, Niemann $H_{\text {, }}$ et al. Luteal blood flow is a more appropriate indicator for luteal function during the bovine estrous cycle than luteal size. Theriogenology 2010;73: 691-7.

[17] Trevisol E, Ferreira JC, Ackermann CL, Destro FC, Filho WCM, Carmagos AS, et al. Luteal changes after treatment with sub-luteolytic doses of prostaglandina (cloprostenol sodium) in cattle. Anim Reprod Sci 2015;153:8-12.

[18] Siqueira LGB, Torres CAA, Amorim LS, Souza ED, Camargo LSA, Fernandes CAC, et al. Interrelationships among morphology, echotexture, and function of the bovine corpus luteum during the estrous cycle. Anim Reprod Sci 2009;115: $18-28$.

[19] Richards MW, Spitzer JC, Warner MB. Effect of varying levels of postpartum nutrition and body condition at calving on subsequent reproductive performance in beef cattle. J Anim Sci 1986:62:300-6.

[20] Viana JHM, Siqueira LGB, Diniz ES, Camargo LS, Oliveira ER, Fonseca JF, et al. Definição de área mínima representativa para análise de imagens ultrasonográficas de corpos lúteos bovinos. Acta Sci Vet 2006;34:578.

[21] Bishop BE, Thomas JM, Abel JM, Poock SE, Ellersieck MR, Smith MF, et al. Splittime artificial insemination in beef cattle: II. Comparing pregnancy rates among nonestrous heifers based on administration of GnRH at AI. Theriogenology 2017;87:229-34.

[22] Pfeifer LFM, Siqueira LG, Mapletoft RJ, Kastelic JP, Adams GP, Colazo MG, et al. Effects of exogenous progesterone and cloprostenol on ovarian folicular development and first ovulation in prepubertal heifers. Theriogenology 2009;72:1054-64.

[23] St Clair EM, Patterson DJ, Schillo KK. Progesterone treatment stimulates follicle growth without affecting LH secretion in prepubertal beef heifers. J Anim Sci 1995;73:222 (Abstract).

[24] Inskeep EK. Preovulatory, postovulatory, and postmaternal recognition effects of concentrations of progesterone on embryonic survival in the cow. J Anim Sci 2004;82:24-39.

[25] Sá Filho OG, Vasconcelos JLM. Regressão prematura do corpo lúteo em bovinos. Vet Zootec 2008;15:220-33.

[26] Cardoso D, Nogueira GP. Mecanismos neuroendócrinos envolvidos na puberdade de novilhas. Arq Cien Vet Zool 2007:10:59-67.

[27] Evans AC, Adams GP, Rawlings NC. Endocrine and ovarian follicular changes leading up to the first ovulation in prepubertal heifers. J Reprod Fertil 1994; 100:187-94.

[28] Sá Filho OG, Thatcher WW, Vasconcelos JLM. Effect of progesterone and/or estradiol treatments prior to induction of ovulation on subsequent luteal lifespan in anestrous Nelore cows. Anim Reprod Sci 2009;112:95-106.

[29] Sá Filho MF, Nasser LFT, Penteado L, Prestes R, Marques MO, Freitas BG, et al. Impact of progesterone and estradiol treatment before the onset of the breeding period on reproductive performance of Bos indicus beef heifers. Anim Reprod Sci 2015;160:30-9.

[30] Sharma RK, Singh JK, Khanna S, Singh I. Ovarian response of prepubertal Murrah heifers to exogenous GnRH. Anim Reprod Sci 2012;133:153-8.

[31] Chemineau P, Pellicer-Rubio MT, Lassoued N, Khaldi GE, Monniaux D. Maleinduced short oestrous and ovarian cycles and sheep and goats: a working hypothesis. Reprod Nutr Dev 2006;46:417-29.

[32] Berisha B, Schams D. Ovarian function in ruminants. Domest Anim Endocrin
2005;29:305-17.

[33] Fonseca JF, Silva Filho JM, Palhares MS, Ruas JRM, Pinto Neto A. Concentração plasmática de progesterona em novilhas receptoras submetidas à administração de rbST, GnRH ou hCG no quinto dia do ciclo estral. Arq Bras Med Vet Zootec 2001;53:1-8.

[34] Borges AM, Torres CAA, Júnior VRR, Ruas JRM, Carvalho GR, Neto AM, et al Desenvolvimento folicular no pós-parto de vacas da raça Gir tratadas com acetato de Buserelina (GnRH) ou Gonadotrofina Coriônica Humana (hCG) R Bras Zootec 2004;33:1396-404.

[35] Pugliesi G, Santos FB, Lopes E, Nogueira E, Maio JRC, Binelli M. Improved fertility in suckled beef cows ovulating large follicles or supplemented with long-acting progesterone after timed-AI. Theriogenology 2016;85:1239-48.

[36] Vasconcelos JLM, Sartori R, Oliveira HN, Guenther JG, Wiltbank MC. Reduction in size of the ovulatory follicle reduces subsequent luteal size an pregnancy rate. Theriogenology 2001;56:307-14.

[37] Tom JW, Pierson RA, Adams GP. Quantitative echotexture analysis of bovine corpora lutea. Theriogenology 1998;49:1345-52.

[38] Davies KL, Bartlewski PM, Pierson RA, Rawlings NC. Computer assisted image analyses of corpora lutea in relation to peripheral concentrations of progesterone: a comparision between breeds of sheep with different ovulation rate. Anim Reprod Sci 2006;96:165-75.

[39] Simões J, Almeida JC, Baril G, Azevedo J, Fonte P, Mascarenhas R. Assessment of luteal function by ultrasonographic appearance and measurement of corpora lutea in goats. Anim Reprod Sci 2007;97:36-46.

[40] Scully S, Evans ACO, Carter F, Duffy P, Lonergan P, Crowe MA. Ultrasound monitoring of blood flow and echotexture of the corpus luteum and uterus during early pregnancy of beef heifers. Theriogenology 2015;83:449-58.

[41] Acosta TJ, Hayashi KG, Ohtani M, Miyamoto A. Local changes in blood flow within the preovulatory follicle wall and early corpus luteum in cows. Reprod 2003;125:759-67.

[42] Acosta TJ, Yoshizawa N, Ohtani M, Miyamoto A. Local changes in blood flow within the early and midcycle corpus luteum after prostaglandin F2 $\alpha$ injection in the cow. Biol Reprod 2002;66:651-8.

[43] Figueira LM, Fonseca JF, Arashiro EKN, Souza-Fabjan JMG, Ribeiro ACS, Oba E et al. Colour Doppler ultrasonography as a tool to assess luteal function in Santa Inês ewes. Reprod Dom Anim 2015;50:643-50.

[44] Siqueira LGB, Areas VS, Ghetti AM, Fonseca JF, Palhao MP, Fernandes CAC et al. Color Doppler flow imaging for the early detection of nonpregnant cattle at 20 days after timed artificial insemination. J Dairy Sci 2013;96:6461-72.

[45] Matsui M, Miyamoto A. Evaluation of ovarian blood flow by colour Dopple ultrasound: practical use for reproductive management in the cow. Vet J 2009; $181: 232-40$.

[46] Guimarães CR, Oliveira ME, Rossi JR, Fernandes CA, Viana JH, Palhao MP. Corpus luteum blood flow evaluation on Day 21 to improve the management of embryo recipient herds. Theriogenology 2015;84:137-41.

[47] Perry GA, Cushman RA. Invited Review: use of ultrasonography to make reproductive management decisions. Prof Anim Sci 2016;32:154-61.

[48] Tamanini C, Ambrogi M. Angiogenesis in developing follicle and corpus luteum. Reprod Dom Anim 2004;39:206-16.

[49] Niswender GD, Juengel JL, Silva PJ, Rollyson MK, Mcintush EW. Mechanisms controlling the functional and life span of the corpus luteum. Physiol Rev 2000;80:1-29. 